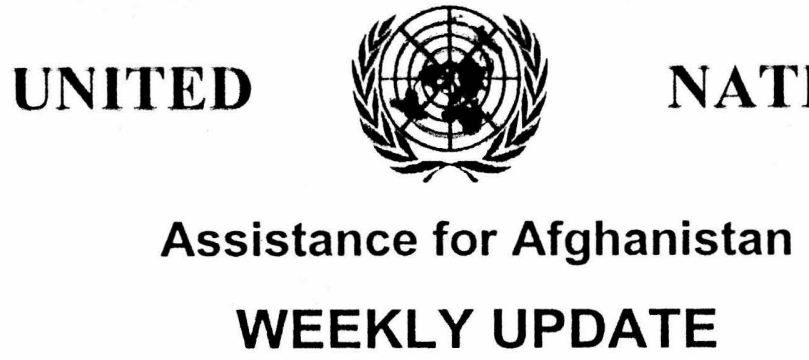

Issue No. 313

\section{SIDA Mission}

The Swedish mission visited Kabul, Faizabad, and Peshawar before departing from Islamabad on $13^{\text {th }}$ May. The visit was in preparation for the meeting of the Afghanistan Support Group in Stockholm during June.

\section{Staff Return}

Six international staff from various UN agencies flew to Mazar-I-Sharif on $17^{\text {th }}$ May. This was the first mission of UN international staff to the area in one and half years. The mission is determining the logistical requirements that need to be in place before the UN can resume an international presence in the area.

\section{Food Aid}

The second phase of the WFP Bamiyan Emergency Relief Operation is set to begin early next week. The first phase of this operation began in the winter of 1998 as a support to vulnerable families in what had been identified as a food deficit area on the basis of data collected earlier in the year by WFP's Vulnerability Analysis and Mapping section (VAM). Stocks are currently being pre-positioned in Jalalabad for distribution to the districts of Waras and Panjao, south of Bamiyan City. Some 15,000 families in Panjao and Waras will receive 1,800 tons of wheat and 150 tons of corn-soy blend
(CSB). Implementation will be carried out jointly with OXFAM. The operation will spread to four other districts (Behsud 1, Behsud 2, Shahristan and Daykundi) in June, following identification of beneficiaries. Implementation at this stage will be carried out in conjunction with the international NGOs MADERA and ACF.

\section{Health/Education}

\section{Immunisation}

WHO in collaboration with MoPH, UNI$\mathrm{CEF}$, and health NGOs completed the first round of National Immunization Days (NIDs) against poliomyelitis in Afghanistan on 11 May, despite disruption caused by fighting in some areas.

More than 19,000 volunteers, health workers, and social mobilizers were mobilized to target 4.3 million children under age of five.

In Kabul, the first round of NIDs was officially inaugurated by Mohammad Abas Akhund, Minister of Public Health, Dr. A. M. Jama, WHO Representative and Mr. Louis-George Arsenault, UNICEF Representative in Khair Khana hospital.

In Mazar City, a big march with the participation of WHO, MoPH, UN agencies, NGOs, local authorities and people was staged on $8^{\text {th }}$ May to express their readiness and support for the NIDs first round. In addition, eight polio-affected children in wheelchairs also attended the 
march. They carried placards with health messages.

In northern region, the vaccination campaign was officially launched in the major cities of Balkh, Samangan, Saripul, Jowzjan and Faryab provinces. More than 42 districts in these provinces were covered.

In Faizabad, WHO divided the implementation of NIDs first round's programme into two phases, because of climatic conditions. The first phase was conducted on $9^{\text {th }}$ May and successfully completed on $11^{\text {th }}$ May in eastern districts, while the second phase is planned to be conducted on $17^{\text {th }}$ May in Kishem, Ragh, Sharibuzarg and Wakhan districts of Badakhshan.

\section{Medical Supplies}

WHO provided medical supplies to the Kunduz Public Health Hospital, Baghlan hospital, Mazar Provincial Hospital, Behsood BHC Clinic, Pul-I-Khumri clinics and in Zabul, Badakshan and Ghazni Provinces.

UNICEF provided stethoscopes, sphygmomanometers, water containers, utensils and other equipment to the maternity, nutrition and other wards of the Herat regional hospital.

\section{Cirrhosis outbreak}

An emergency meeting of MoPH, UN agencies and NGOs was held at the Governor's house to agree on a strategy to tackle the outbreak of cirrhosis, which has killed some 130 people in Gulran District of Herat, 32 within the last six months. A committee was established to monitor and supervise the situation. UNICEF provided high protein biscuits, cooking oil, serum and steel beds to the regional department of $\mathrm{MoPH}$ for the affected area.

\section{Health/Education Training}

WHO distributed about 1,400 copies of booklets, translated in Pushtu and Dari, entitled Water and Health in Islam to all provincial health departments in southern region, including UN agencies, NGOs and local authorities.

WHO has also organised 72 educational sessions this year in various locations of Helmand Province to disseminate health messages.

\section{UNICEF and SCA Nutrition Training}

UNICEF, in collaboration with the Swedish Committce for Afghanistan, conducted a 6day nutrition-training workshop in Peshawar from $2^{\text {nd }}$ to $8^{\text {th }}$ May for fifteen female doctors who supervise $\mathrm{MCH}$ clinics in different regions of Afghanistan. The course put special emphasis on community participation in order to equip participants to start new and improve existing nutrition programmes.

This workshop is first of its series and aims to cover key participants from 60 $\mathrm{MCH}$ clinics run by SCA across Afghanistan. Growth monitoring cards, weighing scales, and MUAC and Dari version of advocacy materials, including the Convention on the Rights of the Child and the Convention on the Elimination of All Forms of Discrimination against Women were distributed. 


\section{Safe Water/Sanitation}

A UNICEF mission monitored the Surkhrud Area Based Project (ABP). It was observed that some latrines were not being properly used. Female social mobilisers were advised to continue educating communities on the proper use of sanitary facilities.

In Farah City, MoPH is starting the chlorination of household wells. UNICEF has provided $50 \mathrm{kgs}$ of chlorine and ORS for distribution during this campaign.

\section{Reconstruction and Rehabilitation}

In Azro district of Logar Province, work has started on the rehabilitation of the Azro-Hesark road, which aims to facilitate travel of returnees.

Following an explosion in an ammunition store in a residential area of district 11, Kabul City, UNCHS distributed plastic sheeting to some 700 households, whose windows were blown out. Work continues on the removal of unexploded ordnance from the site by BAC and ATC teams.

\section{Agriculture}

\section{Livestock}

FAO Kandahar monitored five Veterinary Units (VFUs) in Urozgan Province.

\section{Crops}

FAO transferred 13 motor-bikes from FAO Jalalabad to Kabul for ISRA, one of FAO's implementing partners, district trainers for supervision and monitoring of the inte- grated production and protection programme in Wardak, Logar and Kabul provinces, and transported agricultural inputs from FAO Ghazni to Kabul.

\section{Mine Action Programme}

The UN Mine Action Programme for Afghanistan has cleared 13.9 million square meters of mined and battlefield areas in Afghanistan in 1999 and has completed surveys of 12.4 million square meters. The total mined area remaining is 703 square kilometres. Over $90 \%$ of this is agricultural and grazing land. Since 1990, MAPA has succeeded in destroying close to one million mines and unexploded ordnance in Afghanistan, and has briefed 4.7 million civilians on mine awareness.

Herat and Kandahar Provinces are the two most heavily mined high priority areas for clearance.

\section{Special Focus: Hazarajat Food Secu- rity Update}

The food security situation in Hazarajat was reviewed in a mission to the area organised by the UN Co-ordinator's Office from $29^{\text {th }}$ April to $7^{\text {th }}$ May. As follow up to the missions, an inter-agency food security initiative has been planned.

There was international concern at the food security situation in Hazarajat during 1997 and 1998, as a road blockade of the area pushed up food prices in an area that was already very poor. The take over of the area by the Taliban movement in autumn 1998 produced a peace dividend: roads opened, food prices came down and people were able to sell their animals at a better price. International assistance agen- 
cies, reviewing needs in late 1998, concluded that household assets in the area were at such a low level that achieving a basic minimum degree of food security would require at least a year of peace, economic recovery and hard work by the aid agencies. 4,000 tons of wheat, provided by WFP, were channelled to households affected by the food shortage, in a large scale distribution by leading NGO's working in Hazarajat. This distribution in December 1998/January 1999 covered the poorest quarter of the population, plus people displaced from the 1998 fighting, in the districts of Behsud 1 and 2, Panjao, Waras and Shahristan.

During the April/May Mission, preliminary monitoring of the winter food distribution, in districts Waras and Panjao indicated :

1. Targeting of the assistance was extremely effective, as well informed field workers, helped by local shuras, were able to identify the poorest and most vulnerable households.

2. The wheat that beneficiaries received was a timely and effective assistance package. Many of the beneficiaries who were interviewed during the mission said that this wheat was all they had to eat over the winter and that the assistance operation has thus helped keep them alive.

The Mission noted signs that there is still a significant food security problem in the area. Out-migration of households who do not expect to be able to feed themselves this year continues, especially from the districts of Waras and Daikondi. Daily one to two trucks of migrating families are passing along the main road out of Waras.
The very poorest do not have the assets required to raise the fare out of the area. A range of people in the area have not been able to benefit from the nascent economic recovery. These include those who had already lost virtually all their productive assets, those who are chronically indebted and those who were worst affected by the 1998 local crop failures or the 1999 conflict.

In 1999 conflict has again emerged as a key factor in food security. The Mission noted the successive rounds of fighting in Bamyan and Yakawlang, presence of substantial armed contingents in the area, slow down in commercial movements of grain and renewed large scale displacement of the civilian population. Whether food shortages become acute in 1999 now largely depends on the extent to which the conflict can be contained. Talking with civilians in the area, it was clear that there is a strong consensus in favour of avoiding conflict to allow the economic recovery, to go ahead. People expressed very simple hopes: (1) That the fighting should not come to their area. (2) That the roads should stay open. (3) That affordable wheat should come into the area. (4) That they should get a decent price for the animals that they have to sell. And (5) that the United Nations and international assistance is needed to help them to survive and recover.

The Hazarajat Food Security Coordination Group has now planned a major inter-agency response to the continuing food security needs in Hazarajat. Implementation commences immediately and the operation will last until the end of 1999. This response brings together the UN system, NGOs and the European Union (ECHO). The response will cover some 
250,000 people (out of a population of 840,000 ) in ten districts worst affected by the food shortages. It will combine a range of types of assistance, including food distribution to vulnerable households and cash for work activities.

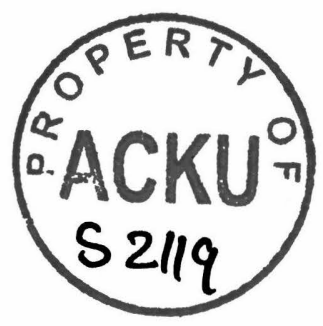

